\title{
Religious Education as Accompanying: from Superficiality to Spirituality to Personal Acquaintance with God Incarnate'
}

\begin{abstract}
The dynamic social, cultural and technological changes which take place in almost all the world have a major impact on religious identity of young generation. Taking into account the crucial role of Religious Education in the process of knowing and meeting with God, the author presents, in this article, Religious Education in schools as accompany young people on their road to the "contemporary Emmaus". It will take into consideration various stages and conditions on the way, which with the help of RE, allows youngsters to discover, recognize and acknowledge God incarnate.
\end{abstract}

\section{Keywords}

Religious Education in schools, youth, accompaniment, spirituality.

\section{Introduction}

Contemporary Europe is a complex and diversified society. We are also aware of the sudden economic, social, cultural, educational and religious changes that are occurring now. Children and young people seem to adapt smoothly to technological, social and cultural changes, but is it so indeed?

1 This text was first presented at the XVII conference of European Forum on Religious Education held at the University of Silesia in Katowice on 30 March - 3 April 2016. 
They certainly are the effective participants of the cultural revolution, often better in communicating with their peers through the Internet rather than directly, but at the same time, their contacts in the family, neighbourhood, ecclesial community are weak; they become hasty, superficial and temporary. ${ }^{2}$ What can Religious Education in schools do in this situation? How can it make young people sensitive to transcendence? Does RE, carry an evangelisation opportunity for pupils who have no contact with Christianity, and if so, to what extent? How can it lead children and young people to meeting and having a long-lasting relationship with Jesus Christ? To what extent, and how, can Religious Education in schools accompany young people in different European countries on their road to the "contemporary Emmaus"? Or maybe a more fundamental question should be asked: why should religion be taught at school?

Seeking answers to the above questions can be difficult for many reasons. Firstly, despite a common European context and the frequently used definition: "global teenager", a pupil's life context differs significantly in different parts of Europe. Secondly, the assumptions and concepts of Religious Education in schools adopted by various countries, and sometimes even by the regions of the countries, maintain their dissimilarity and use different arguments. ${ }^{3}$ Thirdly, the relations between Religious Education in the school and the school, between Religious Education in the school and the parish, Church and catechesis are different. Therefore the solutions that are implemented and bring results in Poland can be incomprehensible and hard to accept in Western Europe. I usually try to indicate catechetical originality and uniqueness of Poland in my lectures, but in this article I would like to present a more general look, which entails the risk of simplification which might cause problems with understanding the situation properly.

The title of the chapter: Religious Education as Accompanying: from Superficiality to Spirituality to Personal Acquaintance with God Incarnate, entrusted

${ }^{2}$ Cf. H. Lombaerts, ICT jako główne wsparcie globalnego świata i globalnego środowiska edukacyjnego, in: Między tradycją a wspótczesnością. I Krajowy Kongres Katechetyczny, eds. A. Bałoniak, J. Szpet, Poznań 2008, pp. 73-90; E. Osewska, J. Stala, Die katholische Schule zu Beginn des XXI. Jahrhunderts am Beispiel Polens und Englands, Warsaw 2015; J. Stala, E. Osewska, Anders erziehen in Polen. Der Erziehungs- und Bildungsbegriff im Kontext eines sich ständig verändernden Europas des XXI. Jahrhunderts, Tarnów 2009; Religious Education / Catechesis in the Family. A European Perspective, ed. E. Osewska, J. Stala, Warszawa 2010.

${ }^{3}$ Cf. R. Jackson, Rethinking Religious Education and Plurality. Issues in diversity and pedagogy, London 2004. 
to me, requires to clarify a few terms and basic assumptions. The first part of the title refers to 'accompanying'. According to the general understanding, accompanying involves first of all being 'in attendance', being with somebody, sharing the hardships of a journey, joys, but also difficulties, uncertainties, overcoming obstacles on the road together, defining the destination. Sometimes, in the post-communist countries, the notion of "accompanying" may also have negative associations for the older generation, relating to the political and social abuse of the word "comrade", e.g. a comrade in arms. The notion of "accompanying" also meant following a person by security agents. If Religious Education wants to take on the function of accompanying children and the youth on the road to the contemporary Emmaus, then the fundamental condition is presence/being in attendance and walking together. Therefore, I would like to encourage all to reflect upon the idea of 'the road' and sharing it with a co-walker going in the same direction and looking for the answers to the fundamental questions. Personal acquaintance with God Incarnate also assumes a certain complementarity of God's initiative and human's action, cognition, conversion and trust. That is why I do not want to discuss faith from the doctrinal perspective, but rather to look at it as a dynamic process. Underlying this process is a disposition (given by God to man) to look around, ask questions, search, and then to gradually acknowledge God's existence, become acquainted with and love God. A man's relationship with God is not static, but dynamic, so it changes continually and is shaped throughout man's life. Search, discovery, difficulty, breakdown, enlightenment, joy, fascination and other experiences become interwoven and have an impact on a Christian. ${ }^{4}$

If the road to discover, recognize and acknowledge God Incarnate is a longterm, personal, individual and, simultaneously, joint process, while fewer and fewer environments and people support a child and a young person on that road nowadays, then RE in the state school definitely presents itself as an opportunity. Other questions also come up, such as: how can a young person growing up in a non-religious reality, fascinated with contemporary culture, communication technology and a multitude of choices, discover the value of being acquainted with God? Is the relationship between the faith (understood as an existential experience, cultural fact, personal experience and the point of reference for a community) and RE still the relationship of interdependence? What type of pedagogy, language and methods should be used to communicate

${ }^{4}$ Cf. E. Osewska, J. Stala, W kierunku katechezy rodzinnej, Kielce 2003. 
with a contemporary pupil? How do we accompany the pupil on the road, where so many opportunities are presented to him/her? All these questions require us, as RE experts, to come forward with in-depth answers. I will try to refer to them further in the text.

\section{At the beginning of the road}

The assumed theme of 'the road' carries the assumption of a starting point, the continuity of the road and its destination, but also the effort that needs to be taken, time that must be devoted to cover the distance, proper preparation to walk it... So let's start from the beginning, from the biblical text: "And behold, two of them were going that very day to a village named Emmaus, which was about seven miles from Jerusalem. And they were talking with each other about all these things which had taken place. While they were talking and discussing, Jesus Himself approached and began travelling with them. But their eyes were prevented from recognizing Him" (Lk 24:13-16). As described by St. Luke the Evangelist, the disciples going to Emmaus are sad, lonely, in despair, feeling lost, terrified that they lost their Master for ever. Overwhelmed by the situation, they are not able to recognize Him, although $\mathrm{He}$ is so close. And what about our pupils? What are they like? What characterizes them at the beginning of their road to the contemporary Emmaus?

Undoubtedly, the transition from one life stage to a new, yet unknown stage, e.g. the transition from the stage of being a small child surrounded by the family to the pre-school or school stage, change of school, the transition from the childhood stage to the youthfulness stage, and then from youthfulness to adulthood, is a difficult period in the development of every person. At present, the phenomenon of the so-called "hurried child" - hurried by media culture, the transition from childhood to youthfulness - is frequently pointed out. Adolescence is now becoming an especially difficult period: when teenagers are looking for their own individuality, their own place in the world, their own identity. This manifests itself in the known phase of rebellion and questioning of authority figures, enhanced nowadays by global corporations creating their consumer. Parents are not always aware of the importance of this period for development, hence teenager's problems are sometimes regarded as petty or ignored. Young persons, not finding understanding from adults, feel rejected and lonely. They experience a double feeling of loneliness - on the one hand they 
often cannot get the necessary support from the parents, and other adults, on the other hand - when their attempts of being independent are undermined - the process of building a sense of their own identity and value is hindered. Young persons' loneliness means both the lack of strong bonds with other people and the lack of contact with oneself. A contemporary pupil does not find inner strength in solitude, but only encounters a feeling of desolation, suffering and emptiness. He/she needs another person, needs understanding and acceptance, recognition and appreciation, and at the same time, while not understanding him/herself and resorting to own emotions, he/she rejects others attention which he/she needs so much. The phenomenon of young people questioning authority figures in the adolescence period also manifests itself very strongly. Psychologist Z. Płużek believes that a tendency to reject or question authority figures due to a development crisis is a type of an identity crisis which consists in, inter alia, asking oneself: who am I, what is important for me, what outlook on the world do I want to adopt, what do I want do to in my life? This is also connected with choosing the values a given person wants to adhere to in his/her actions, and with looking for ideals and life goals. ${ }^{5}$ The transition to a new life stage is also the time to discover that parents are not omnipotent. This shakes the sense of a young person's security. This problem is enhanced considerably by postmodernism and secularization related phenomena. The lack of authority figures, community, permanent point of reference, and civilisation-related threats bear uncertainty, anxiety, fear and a feeling of being lost. ${ }^{6}$ All the described phenomena related to pupil's inner chaos, enhanced additionally by external chaos, set very high requirements for RE teachers. If Religious Education in schools is to accompany the pupil on the road, then it must accept young people's experiences related to the transition from one development stage to another. The feeling of being lost, helpless, desperate, lonely and afraid experienced by many pupils becomes the starting point or part of the joint road. The basic tasks comprise being in attendance, being patient, properly communicating and making an effort to understand. These are high requirements for RE teachers. ${ }^{7}$ Religious Education must face the rule of patience, regularity and wise communication to be able to

${ }^{5}$ Cf. Z. Płużek, Psychologia pastoralna, Kraków 1994, p. 103.

${ }^{6}$ Cf. J. Mastalski, Samotność globalnego nastolatka, Kraków 2007.

${ }^{7}$ Cf. E. Osewska, The Current Situation of Education and Continuing Professional Development of RE Teachers in Poland in the Context of the Social Challenges, "The Person and the Challenges" 2 (2012) no. 2, pp. 123-131. 
listen aptly to pupils' voices, learn about their life stories, and at the same time not to succumb to the temptation of paedocracy.

\section{Sensitizing to the spiritual sphere}

According to research conducted under the European Values Study, the number of people regarding themselves as religious continually diminishes on our Continent, especially in the northern and western parts of Europe. 27.9\% of Europeans do not participate in religious practices regularly, although occasional participation in church services is still important to them on account of lifetime events, such as: child birth (71.3\%), wedding (73.2\%) or death of a family member (81.9\%). ${ }^{8}$ The "pick and choose" attitude has become more and more popular indicating that Europeans are eclectic and choose their beliefs, traditions and religious practices based on their individual choice rather than on religious guidelines. Individual experiences of religiousness becomes more and more often religiousness without dogmas, principles, norms. ${ }^{9}$ As a consequence, the number of people who give up moral principles and the doctrine of a given Church for the benefit of their own, individualized and eclectic religiousness is growing systematically. What emerges in Europe is the transition from the strong position of Christianity, through the co-existence of different religions and atheism, to a characteristic religious sentiment characterised by individualization, subjectivism, aestheticism, emotionalization, ethicality and indifferentism. ${ }^{10}$ This description might be a significant indication for $\mathrm{RE}$, since there will be few pupils in one class with a clearly defined religious identity. There will be more supporters of individually created religiousness and pupils appreciating their own religious experiences, the followers of the so-called "religion of the heart", human rights defenders, pragmatics, the religiously indifferent, lost and antireligious. The multitude and diversity of the participants of RE classes is the fact that carries a challenge for Religious Education in schools.

${ }^{8}$ Cf. Atlas of European Values: Trends and Traditions at the turn of the Century, eds. L. Halman, I. Sieben, M. van Zundert, Leiden 2011.

${ }^{9}$ Cf. M. Mariański, Sekularyzacja i desekularyzacja w nowoczesnym świecie, Lublin 2006, p. 101.

${ }^{10}$ Cf. J.-P. Willaime, Europe et religions. Les enjeux du XXIe siècle, Paris 2004, p. 67. 
When religion is regarded as a commodity/product in a supermarket or own, subjective religion is created that can change due to pupil's emotions, the following question arises: How can we help a child and a young person who feels lost in postmodern chaos be sensitive to the presence of God? A young person who feels lost, distracted, confused and in deep dissonance between his/ her personal life and ideals, who craves love and rejects love at the same time, becomes incomprehensible to him/herself. Unfortunately, modern technological development and financial prosperity does not translate directly into spiritual wellbeing. It seems that there are no more dangerous situations for pupils than longing for love and happiness, while remaining on the level of material goods. Religious education, while starting from human longing and should indicate life dissonance: a rift between the ideals and attempts to reach them. ${ }^{11}$ Different methods should be used to indicate that financial security alone and focusing on what is carnal, will not satisfy man's longing.

While looking for own identity, a young person asks him/herself: who am I? What is the goal and sense of my life? What am I looking for? Therefore, it is necessary on the road to Emmaus to talk, ask questions and seek answers jointly and patiently to help the pupil discover who he/she is and to face one's own secret. As long as the pupil does not want to start the search, reflection, pondering over one;s own life, he/she will not develop the spiritual sphere. It is not enough to refer to the body, intellectual or emotional sphere (although you can start with them sometimes), since they will not bring the final answer to the question: who is man?

In the postmodern and secular society, it has become almost a policy to reduce human desires to focus only on the body (diets, health, physical fitness) and emotional wellbeing, hence RE needs to sensitize pupils to the beauty of nature, art, culture, good done by people, truth seeking, so that the pupil longing for the ideal does not stop on the road focusing solely on own outward appearance. The forms of assistance in gradual spiritual development can and should even vary. A good type of assistance in this respect can be teaching a pupil to look at him/herself and him/her life in a realistic and honest way, asking about the sense of life, the hierarchy of values, unmasking caricatured visions of man. ${ }^{12}$ Accompanying the pupil on the road to Emmaus calls for higher openness to the pupil's needs and search. It is necessary to ask the pupil questions about his/her

${ }^{11}$ Cf. Evangelii nuntiandi 51.

12 Cf. M. Dziewiecki, Wychowanie w dobie ponowoczesności, Kielce 2002, pp. 87-95. 
own desires and support him/her not to settle for superficial answers given by modern media culture, but to persevere in searching further. Thus the pupil will gradually step forward on the road from imposed superficiality to spirituality.

\section{Existential experiences}

When accompanying the pupil on the road, RE in schools cannot ignore pupils' life situation and everyday experiences. Strong, negative experiences: loneliness, fear, suffering, pain, sadness, sickness, failure, which prompt the pupil to stop and reflect on him/herself and life, are most important. Sometimes, without the assistance of a road companion, the experiences of pain and suffering can lead to rejecting faith in God, but sometimes experiencing ultimate situations with the whole range of emotions leads to the discovery of God, as J. Tischner wrote: "to come near to God, you have to deal with the question about evil"."13 Questions about sickness, suffering, evil must be addressed by RE in schools.

For many contemporary youth, music, fine arts and artistic work in virtual space provide an important means of expressing oneself. Experiencing oneself and everyday situations in an intensely emotional manner prompts the pupils to express their experiences. ${ }^{14}$ Simultaneously, when entering the sphere of beauty, the pupil finds something that goes beyond his/her everyday reality, discovering the signs of God. ${ }^{15}$ Through the beauty of arts, the pupil is not only able to gradually admire a direct creator, but can also get to know the First Creator ontologically. Focusing on fine arts may lead a young person to the moment, in which the act of admiration will become a religious and mystical act. The special nature of arts consists in that the visual and music art forms refer to the human ability to see and hear. ${ }^{16}$ The experience of faith arises from listening to the word, but also from looking at Jesus Christ's work. Thanks to

${ }^{13}$ Cf. J. Tischner, Myślenie na skrzyżowaniu dróg, in: Człowiek i transcendencja, ed. K. Tarnowski, Kraków 1995, p. 7.

${ }^{14}$ Cf. W. Kawecki, Teologia piękna. Poszukiwanie locus theologicus w kulturze wspótczesnej, Poznań 2013.

15 Cf. Education and Creativity, ed. E. Osewska, Warszawa 2014.

${ }^{16}$ Cf. J. Królikowski, Zobaczyć wiarę. Obraz i doświadczenie wiary w Kościele, in: Wierzyć i widzieć, eds. K. Flander, D. Jaszewska, W. Kawecki, B. Klocek di Biasio, E. Mazur, N. Mojżyn, J. S. Wojciechowski, M. Wrześniak, D. Żukowska-Gardzińska, Sandomierz 2013, pp. 127-129. 
His Incarnation God has become audible and visible. It can be assumed that the "inner interchangeability" of the word and image occurs in Jesus Christ, which is confirmed by Christological Titles: Logos-Word and Eikon-Image. Therefore, accompanying the pupil on the road to Emmaus should include both the verbal and visual processes, ${ }^{17}$ especially now that the use of imagination and iconic language by young people is intensifying.

Looking for, craving and experiencing love is also a significant educational experience. Sometimes the pupil needs the experience of love so much that he/ she succumbs to the first experienced emotions of being infatuated, mistaking them for love. However, one can assume that the very craving for giving love and receiving love from a chosen person is such a strong experience that it helps the pupil open up to God's love towards man. The experience of love, and the craving for being happy, experienced by young people especially intensely meets with a favourable response of finding God. RE in schools, accompanying the pupil on the road, should gradually help him/her to recognise own emotions and deal with them, and also to use their own reasoning in a responsible way, and refer wisely to another person. Continuous accompaniment and support enhances the pupil's emotional upbringing and search for the truth. A young person gradually gains self-awareness and can carry out self-evaluation. Finding out the truth of self, of own virtues and vices, of things that develop him/her and lead to happiness, and of things that threaten and destroy him/her, provides the basis to start the process of religious upbringing. ${ }^{18}$

A young person who discovers who he/she is, respects him/herself, carries out further responsible self-evaluation and respects other. He/She, can set off on the road further supported by the religion taught at school that enhances his/her will and motivation. However, we must remember that obstacles that emerge on the road (unwillingness to make an effort, weak will, peer influence,

17 Cf. J. Królikowski, Widzialne słowo. Teologia w sztuce, Tarnów 2009; W. Kawecki, Teologia wobec kultury wizualnej, in: Miejsca teologiczne w kulturze wizualnej, Kraków - Warszawa 2013, pp. 15-29; Kultura wizualna - teologia wizualna, eds. W. Kawecki, J. S. Wojciechowski, D. Żukowska-Gardzińska, Warszawa 2011; J. Stala, Punina postojanja osobe - civilizacija ljubavi u kontekstu postmoderne, „Crkva u svijetu” (2015) no. 3, pp. 469-477; J. Stala, Die Polen angesichts der Umbrüche im politischen und gesellschaftlichen Bereich. Ein Vierteljahrhundert nach der Unabhängigkeit Polens, „The Person and the Challenges“ 5 (2015) no. 1, pp. 191-199; J. Stala, Katechese im Zeitalter der Postmoderne. „Grundsatzprogramm für die Katechese der Kirche in Polen“ aus dem Jahr 2010, „Bogoslovni vestnik“ 74 (2014) no. 1, pp. 107-117.

${ }^{18}$ Cf. M. Dziewiecki, Wychowanie w dobie ponowoczesności, Kielce 2002, pp. 55-67. 
interesting media offers) can block the journey, thus it is necessary to support the pupil regularly and enhance his/her motivation continually.

\section{Overcoming obstacles on the road}

To prepare the pupil for the meeting God Incarnate, RE teacher needs to indicate arguments for His reliability and real historical presence. By mentioning specific, historical documents confirming the historicity of Jesus Christ, RE prevents the accusations of His fictionality. However, the acknowledgement of historicity alone confirms only His presence on earth, it may present Him only as an exceptional man and master, hence it needs to be completed by pointing out to His passion, death and resurrection. If the pupil is to perceive Jesus Christ as someone who is more than the founder of Christianity, you also need to indicate the arguments for His divinity: divine self-consciousness, the uniqueness of His relationship with God Father, moral attitude, acceptance of His passion and death by crucifixion, the fulfilment of Old Testament prophecies, performing miracles and resurrection. It is especially important to present the fact of resurrection and related events: the reality of Jesus' death, empty grave, Christophanies and fidelity of His disciples until suffering martyrdom eventually. ${ }^{19}$

A blotted out, untrue or incomplete image of Jesus can pose a great obstacle on the road to meeting Him. How can I recognize God Incarnate, when I do not know who He is? How do I meet Somebody who is portrayed in caricature by the mainstream media? Unfortunately, it often turns out that the pupil creates the image of God resembling man, totally incompatible with the message of the Bible. The limitation of human cognition, upbringing errors, media messages, bad experiences with people representing the Church make the pupil create a distorted image of God, sometimes excessively demanding, whom you are not able to love, and sometimes excessively indulgent and naïve, who can easily be reduced to a cultural image or a children's story. ${ }^{20}$

St. Luke the Evangelist reminds that the disciples were not able to accept the prophets' messages on the road to Emmaus, hence Jesus himself "beginning with Moses and with all the prophets, He explained to them the things concerning

19 Cf. P. Mąkosa, Katecheza młodzieży gimnazjalnej w Polsce. Stan aktualny i perspektywy rozwoju, Lublin 2009, pp. 433-438.

${ }^{20}$ Cf. E. Osewska, J. Stala, W kierunku katechezy rodzinnej, Kielce 2003, pp. 185-194. 
Himself in all the Scriptures" (Lk 24:27). Therefore, on the next stage of the journey, when the pupil accepts the existence of God Incarnate, at his/her youthful level, it is necessary to become further acquainted with God through the Bible and Tradition. Depending on pupil's needs, current knowledge, skills and life context, teaching religion should give him/her support. The pupil cannot be left at the stage of recognizing God Incarnate as existing, but should be accompanied further on the road. The more anti-religious or indifferent the pupil's environment is, the more profound the forms of support need to be, from specific religious literacy, through intellectual cognition, interpretation to proclaiming the kerygma, Christian Testimonies and prayer based on Bible verses. It is extremely important to keep the language of the message appropriate, so that the pupil is gradually encouraged, "pulled" to discover God Incarnate further. The problem of inculturation emerges especially intensely at this moment. As K. Misiaszek reminds, teaching religion must take the cultural context of pupil's life into account, since culture is the pupil's first and primary environment and way of life, and religion emerges in culture. ${ }^{21} \mathrm{~A}$ deep rift between culture and religion experienced currently in Europe is the cause of the tragedy of our times. ${ }^{22}$ Therefore, if the Word of God is to reach a contemporary pupil, RE must be inculturated nowadays. RE will not establish a relationship with the pupil and will not be able to accompany him/her on the road, if it does not consider culture in a broad sense and fails to permeate through, interpret and heal it competently.

We must not forget about one more issue related to the contemporary cultural context - the virtual reality created by new electronic communication. It is where the pupils communicate, play, rest but also acquire knowledge. "Digital literacy" - the ability to search for, understand and apply information coming from various sources and presented through the Internet - is becoming very valuable. The contemporary pupil draws contents, also religious, from many sources of different value. He/she combines, repeats or processes and forwards them. ${ }^{23}$ In this context, RE is to help a young person to differentiate between

${ }^{21}$ Cf. K. Misiaszek, Koncepcja nauczania religii katolickiej w publicznej szkole włoskiej po konkordacie z 1984 roku, Warszawa 1999, pp. 195-202; K. Misiaszek, Katecheza i kultura, in: Wybrane zagadnienia z katechetyki, ed. J. Stala, Tarnów 2003, pp. 21-71.

${ }^{22}$ Cf. Evangelii nuntiandi 20.

${ }^{23}$ Cf. H. Lombaerts, E. Osewska, Information and Communication Technology, in: S. Gatt, H. Lombaerts, E. Osewska, A. Scerri, Catholic Education. European and Maltese Perspectives, 
imitation, superficiality and wise, honest and true reflexion whilst $\mathrm{w}$ calling for action compliant with insight gained into oneself.

Becoming acquainted with God Incarnate in a specific social and cultural context leads to the call and the risk of transformation. God Incarnate offers to a young person the love which he/she longs for, but calls him/her to respond maturely with the whole life. When reading the Bible, the pupil discovers that God is personalised love and loves Him irrevocably. St. Luke the Evangelist indicates this important moment: "And their eyes were opened and they recognized Him" (Lk 24:31). Recognising who God is, bending over every man, becomes the call to change one's life. Discovering that God is by his/her side and loves him/her always and unconditionally enables the pupil to go from the feeling of being lost, lonely, superficial, distracted to be him/herself again, have a relationship, depth and integrity. Christian experience not only gives the pupil the feeling of security in God's presence, but also calls the pupil to transform from the inside out into a new person. The person who lives with the experience of meeting God Incarnate, deepens it through prayer, reading the Bible, sacramental life, regular religious practices, retreats, fulfilment of God's commandments and life in the community. At this point, RE in schools is not sufficient any more and it needs to point out to young people the places of their faith formation: parish catechesis, religious movements for young people, liturgical, prayer, biblical, charity, ecumenical groups, etc.

John Paul II in his letter to young people reminded: "Man needs this loving look. He needs to know that he is loved, loved eternally and chosen from eternity. At the same time, this eternal love of divine election accompanies man during life as Christ's look of love. And perhaps most powerfully at the moment of trial, humiliation, persecution, defeat, when our humanity is, as it were, blotted out in the eyes of other people, insulted and trampled upon. At that moment the awareness that the Father has always loved us in his Son, that Christ always loves each of us, becomes a solid support for our whole human existence". ${ }^{24}$

Malta 2004, pp. 113-130; E. Osewska, Leducazione oggi in un Europa diversificata, in: Europa, scuola, religioni. Monoteismi e confessioni cristiane per una nuova cittadinanza europea, ed. F. Pajer, Torino 2005, pp. 47-64.

${ }^{24}$ Cf. John Paul II, Apostolic Epistle Parati Semper to the Young People of the World, 7. 
The experience of meeting God can be so strong that it needs to be expressed and looks for various forms of expression. The pupils need spaces, forms of expression, language, specific means to express their "eye opening", meeting, clinging to and relating with God Incarnate. An example of expressing and communicating the experience of meeting God are the World Youth Days, both taking place on Palm Sunday every year as diocesan meetings, and organised as international meetings.

\section{Bibliography}

Atlas of European Values: Trends and Traditions at the turn of the Century, eds. L. Halman, I. Sieben, M. van Zundert, Leiden 2011.

Człowiek i transcendencja, ed. K. Tarnowski, Kraków 1995.

Dziewiecki M., Wychowanie w dobie ponowoczesności, Kielce 2002.

Education and Creativity, ed. E. Osewska, Warszawa 2014.

Jackson R., Rethinking Religious Education and Plurality. Issues in diversity and pedagogy, London 2004.

Kawecki W., Teologia piękna. Poszukiwanie locus theologicus w kulturze współczesnej, Poznań 2013.

Kawecki W., Teologia wobec kultury wizualnej, in: Miejsca teologiczne w kulturze wizualnej, Kraków - Warszawa 2013, pp. 15-29.

Królikowski J., Widzialne słowo. Teologia w sztuce, Tarnów 2009.

Królikowski J., Zobaczyć wiarę. Obraz i doświadczenie wiary w Kościele, in: Wierzyć $i$ widzieć, eds. K. Flander, D. Jaszewska, W. Kawecki, B. Klocek di Biasio, E. Mazur, N. Mojżyn, J. S. Wojciechowski, M. Wrześniak, D. Żukowska-Gardzińska, Sandomierz 2013, pp. 127-129.

Kultura wizualna - teologia wizualna, eds. W. Kawecki, J. S. Wojciechowski, D. Żukowska-Gardzińska, Warszawa 2011.

Lombaerts H., ICT jako główne wsparcie globalnego świata i globalnego środowiska edukacyjnego, in: Między tradycją a współczesnością. I Krajowy Kongres Katechetyczny, ed. A. Bałoniak, J. Szpet, Poznań 2008, pp. 73-90.

Lombaerts H., Osewska E., Information and Communication Technology, in: S. Gatt, H. Lombaerts, E. Osewska, A. Scerri, Catholic Education. European and Maltese Perspectives, Malta 2004, pp. 113-130.

Mariański M., Sekularyzacja i desekularyzacja w nowoczesnym świecie, Lublin 2006.

Mastalski J., Samotność globalnego nastolatka, Kraków 2007.

Mąkosa P., Katecheza młodzieży gimnazjalnej w Polsce. Stan aktualny i perspektywy rozwoju, Lublin 2009. 
Misiaszek K., Koncepcja nauczania religii katolickiej w publicznej szkole włoskiej po konkordacie z 1984 roku, Warszawa 1999.

Osewska E., L'educazione oggi in un Europa diversificata, in: Europa, scuola, religioni. Monoteismi e confessioni cristiane per una nuova cittadinanza europea, ed. F. Pajer, Torino 2005, pp. 47-64.

Osewska E., Stala J., Die katholische Schule zu Beginn des XXI. Jahrhunderts am Beispiel Polens und Englands, Warszawa 2015; J. Stala, E. Osewska, Anders erziehen in Polen. Der Erziehungs- und Bildungsbegriff im Kontext eines sich ständig verändernden Europas des XXI. Jahrhunderts, Tarnów 2009.

Osewska E., Stala J., W kierunku katechezy rodzinnej, Kielce 2003.

Osewska E., The Current Situation of Education and Continuing Professional Development of RE Teachers in Poland in the Context of the Social Challenges, "The Person and the Challenges" 2 (2012) no. 2, pp. 123-131.

Płużek Z., Psychologia pastoralna, Kraków 1994.

Religious Education / Catechesis in the Family. A European Perspective, eds. E. Osewska, J. Stala, Warszawa 2010.

Stala J., Die Polen angesichts der Umbrüche im politischen und gesellschaftichen Bereich. Ein Vierteljahrhundert nach der Unabhängigkeit Polens, "The Person and the Challenges“ 5 (2015) no. 1, pp. 191-199.

Stala J., Katechese im Zeitalter der Postmoderne. „Grundsatzprogramm für die Katechese der Kirche in Polen“ aus dem Jahr 2010, „Bogoslovni vestnik“ 74 (2014) no. 1, pp. 107-117.

Stala J., Punina postojanja osobe - civilizacija ljubavi u kontekstu postmoderne, „Crkva u svijetu" (2015) no. 3, pp. 469-477.

Willaime J.-P., Europe et religions. Les enjeux du XXIe siècle, Paris, 2004.

Wybrane zagadnienia $z$ katechetyki, ed. J. Stala, Tarnów 2003. 